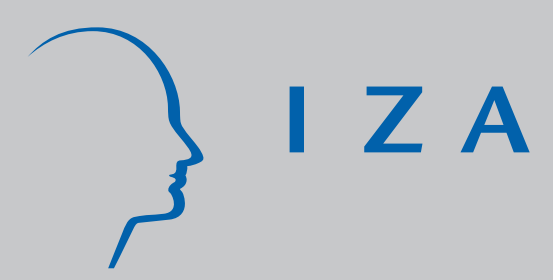

IZA DP No. 5877

Informal Caring and Labour Market Outcomes

Within England and Wales

Stephen Drinkwater

July 2011

Forschungsinstitut

zur Zukunft der Arbeit

Institute for the Study

of Labor 


\title{
Informal Caring and Labour Market Outcomes Within England and Wales
}

\author{
Stephen Drinkwater \\ WISERD, Swansea University, \\ CREAM, University College London \\ and IZA
}

\section{Discussion Paper No. 5877}

July 2011

\author{
IZA \\ P.O. Box 7240 \\ 53072 Bonn \\ Germany \\ Phone: +49-228-3894-0 \\ Fax: +49-228-3894-180 \\ E-mail: iza@iza.org
}

\begin{abstract}
Any opinions expressed here are those of the author(s) and not those of IZA. Research published in this series may include views on policy, but the institute itself takes no institutional policy positions.

The Institute for the Study of Labor (IZA) in Bonn is a local and virtual international research center and a place of communication between science, politics and business. IZA is an independent nonprofit organization supported by Deutsche Post Foundation. The center is associated with the University of Bonn and offers a stimulating research environment through its international network, workshops and conferences, data service, project support, research visits and doctoral program. IZA engages in (i) original and internationally competitive research in all fields of labor economics, (ii) development of policy concepts, and (iii) dissemination of research results and concepts to the interested public.
\end{abstract}

IZA Discussion Papers often represent preliminary work and are circulated to encourage discussion. Citation of such a paper should account for its provisional character. A revised version may be available directly from the author. 


\section{ABSTRACT \\ Informal Caring and Labour Market Outcomes Within England and Wales}

This paper focuses on the links between informal care provision and labour market activity at the sub-national level. Within-country analysis of this issue has been very limited to date despite the wide regional variations in informal care provision that often exist. This issue is important in the context of policy decisions in Wales and other parts of the UK because of relatively high levels of informal caring in certain areas, especially in the South Wales Valleys. In particular, given that these areas typically have the lowest economic activity and employment rates, labour market differences can be exacerbated by the provision of informal caring by people of working age. Despite the wide variations in informal care provision, it is found that labour market outcomes do not differ markedly by different care categories across spatial areas within England and Wales. However, the analysis reveals that labour market outcomes for males as well as females are heavily influenced for those who provide high levels of caring, especially in the South Wales Valleys. For example, the largest impact of caring on the probability of not working for males and for part-time work for females is seen in this area.

JEL Classification: J22, R23

Keywords: informal care provision, labour market outcomes, area variations

Corresponding author:

Stephen Drinkwater

School of Business and Economics

Swansea University

Singleton Park

Swansea, SA2 8PP

United Kingdom

Email: s.j.drinkwater@swansea.ac.uk

\footnotetext{
* The 2001 SAM is provided through the Cathie Marsh Centre for Census and Survey Research (University of Manchester), with the support of the ESRC and JISC. All tables containing Census data, and the results of analysis, are reproduced with the permission of the Controller of Her Majesty's Stationery Office and the Queen's Printer for Scotland. Helpful comments have been received from David Blackaby, Howard Davies, Phil Murphy, Peter Sloane and participants at the WISERD Annual Conference 2010 and at the National Institute for Economic and Social Research Employment Seminar Series. This publication is based on research supported by the Wales Institute of Social and Economic Research, Data and Methods (WISERD), which is funded by the UK Economic and Social Research Council (Grant number: RES-576-25-0021) and the Higher Education Funding Council for Wales.
} 


\section{Introduction}

As the level of informal care that is provided has risen across countries, researchers have become increasingly interested in the impact that caring activities have on other uses of time. In particular, an expanding literature has emerged over the past couple of decades on both sides of the Atlantic on the relationship between informal care and labour market activities. Early US studies (Stone and Farley-Short, 1990; Boaz and Muller, 1992) first highlighted the large impact that informal care can have on labour market outcomes. Subsequent studies have considered the effect that the possible endogeneity of the informal caring decision could have on estimates and some also find a strong link between care provision and labour market outcomes (Ettner, 1995). For the UK, Carmichael and Charles $(1998,2003)$ examined the relationship between informal care provision and a range of labour market variables. They report fairly large effects of informal caring on labour market outcomes, including lower activity rates and earnings, especially for females providing more than 20 hours of care. Studies that pay attention to issues of endogeneity also find that informal care provision can have an important impact on labour force participation (Heitmueller, 2007). In more recent years, studies have also emerged from other countries, including by Leigh (2010) for Australia, Do (2008) for South Korea, Maurer-Fazio et al. (2011) for China and Bolin et al. (2008) and Vittanen (2010) for several European countries. However, there appears to be very little in the literature that considers the link between informal care and labour market outcomes below the national level. This is a potentially important omission given that the incidence of care provision can vary considerably across geographic space and can thus impact differently on labour market outcomes in different places. This paper attempts to fill this void by investigating the relationship between informal care provision and several labour market variables across different areas within England and Wales. It primarily focuses on an area where the provision of informal care is particularly high, namely the South Wales Valleys.

In addition to the literature on informal caring and its links with the labour market, there are also several studies that examine the causes of economic inactivity, focusing particularly on spatial variations within the UK (Fothergill, 2001; O'Leary et al., 2005). Economic inactivity has been a major problem in some parts of the UK in recent decades, especially in areas such as the South Wales Valleys (Blackaby et al., 2003). In particular, it has been argued that inactivity is strongly linked to the decline in traditional sectors of employment in former industrialised areas, contributing to high rates of illness and often leading to the withdrawal of older workers (especially males), reporting some form of health problem, from the labour force. As a result, a relatively high proportion of working age individuals in areas which have seen industrial decline claim incapacity or similar types of benefits rather than being employed or claiming unemployment benefits and seeking work. 
Evidence of this is provided by Beatty et al. (2007), who examine changes in economic activity in former coal mining areas within England and Wales and report that the proportion of males on incapacity benefit was highest in South Wales, with $18.5 \%$ of working age males on such benefits compared to $13.4 \%$ across the coalfield areas as a whole. Moreover, economic activity and employment rates are also low for females in these areas. However, one aspect that generally seems to have been overlooked in these studies is the impact that informal caring activities for friends and family have on labour market outcomes. Therefore, by exploring the link between informal caring and labour market activities, for both males and females, the analysis in this paper aims to shed further light on some of the issues that surround differences in labour supply decisions between geographic areas.

In addition to the focus on sub-national considerations, another key feature of the analysis undertaken in this paper is the estimation of models separately by gender, due to the relatively high level of caring that is undertaken by some males. The analysis also takes account of health, given that carers often report problems associated with long-term sickness themselves. Some of the main findings from the econometric estimates include that employment rates are significantly lower for males and females providing more than 20 hours of informal care in each of the areas under investigation. Certain socio-economic characteristics such as education also exert a strong influence on employment outcomes in each of the areas, as well as across different care categories. Some interesting spatial variations can also be detected including that even though the relationship between caring and employment probabilities is generally stronger for females, it is larger for males in the South Wales Valleys. The impact of providing intensive levels of caring on part-time employment for females is also relatively high in the South Wales Valleys.

\section{Informal Caring and Labour Market Outcomes}

There is now quite a large literature which considers the association between informal caring and labour market outcomes. Many of these empirical studies have used either US or UK data and indeed the development of the literature in the two countries has been quite similar. For example, in the US, the early literature generally found that there were significant opportunity costs in the labour market to informal caring (Stone and Farley-Short, 1990; Boaz and Muller, 1992). In contrast, Wolf and Soldo (1994) use a simultaneous equations approach and found only small effects of care provision on the employment and hours of work of married females. More recent studies have tended to focus on the effect of possible endogeneity between caring and labour market activities. These include those of Ettner (1995, 1996) and Pezzin and Shone (1999), who have applied a range of instrumental variable (IV) techniques in their attempts to identify the causal impact of caring on labour market outcomes. Even after the application of IV techniques, significant reductions in work 
hours are still reported for females providing informal care, which was primarily due to them leaving the labour force (Ettner, 1995).

With respect to the UK, Arber and Ginn (1995) and Carmichael and Charles (1998, 2003) use the General Household Survey (GHS) to examine the relationship between care and labour market outcomes. For example, Carmichael and Charles (1998) examine 1985 data to estimate the effect of caring on economic activity, wages and hours for females. They argue that the effect of caring on labour market outcomes becomes important for those females providing more than 20 hours of care, with much lower activity and earnings amongst this group. Carmichael and Charles (2003) use the 1990 survey to compare differences between males and females and, although caring reduces employment probabilities and pay for both, find that the negative effect is larger for females. Arber and Ginn (1995) use the same data to examine specific aspects of gender differences in the relationship between informal caring and paid-employment. Heitmueller (2007) focuses solely on labour market participation but attempts to control for endogeneity in several ways using the British Household Panel Study (BHPS). By using a range of instruments and the panel element of the BHPS, he argues that the previous UK studies have over-estimated the impact of care on labour market participation. Heitmuller (2007) also investigates differences according to whether the individual is a co-residential or extra-residential carer. He reports that the impact for co-residential carers is much larger than for extra-residential carers, with no significant impact on labour market participation for the latter group of carers.

Few studies appear to focus on this issue at the sub-national level. On exception is Jones and Latreille (2008), who report some descriptive results just for Wales using the 1998 Welsh Health Survey. In common with the UK-wide studies summarised above, they find that employment rates are far lower for people providing more than 20 hours of care per week. The reported employment rate for these intensive providers of care were much lower for both males and females, since they were less than $50 \%$ for both groups, compared with over $70 \%$ for people providing less than 20 hours of care. Informal care is also associated with a higher incidence of part-time employment, with $31 \%$ of carers in employment found to work part-time, in comparison to $18 \%$ of non-carers.

The existing literature therefore tends to highlight a strong relationship between informal care provision and labour market outcomes, even after taking account of the possible endogeneity of caring. However, despite large spatial variations in the provision of care (Shaw and Dorling, 2004; Norman and Purdham, 2010), as well as very large differences in participation in local labour markets in the UK (Beatty and Fothergill, 2005), there is currently very little evidence on the links between care and labour market outcomes at the sub-national level. The analysis in this paper attempts to address this deficiency, especially by focusing on the South Wales Valleys (SWV), which has been identified as the 
area with the highest incidence of informal caring in England and Wales (Norman and Purdham, 2010). In addition, the SWV is generally acknowledged as having some of the highest rates of economic inactivity (Blackaby et al., 2005) and hidden unemployment (Beatty and Fothergill, 2005) in the UK. Therefore, there appears a high degree of correspondence between the areas where the highest percentage of informal carers can be found and those where the greatest levels of hidden unemployment are observed.

The concept of hidden unemployment relates to the movement of former workers, especially males, from the unemployment register onto incapacity benefit. As a result, just focusing on 'official' unemployment rates, especially using the claimant count definition produces a gross underestimate of the extent of worklessness in some areas. The hidden unemployment rates calculated by Beatty and Fothergill (2005) for districts in England and Wales are therefore likely to provide a more accurate indication of geographical variations in labour market slackness. These rates are highly influenced by the proportion of residents claiming incapacity benefit and severe disablement allowance, which are highest in former industrial areas in the North East of England, Merseyside, Yorkshire and South Wales. Using data from August 2003, Beatty and Fothergill (2005) report that although the highest sickness claimant rates were found in Easington in the North East of England, the districts with the next three highest rates were all located in the SWV. Moreover, six of Britain's top ten districts with the highest level of sickness benefit claimants were to be found in the SWV, with this area's remaining district, Torfaen, ranked just outside at number thirteen. Taken together, this evidence highlights the distinctive nature and some of the problems facing the SWV.

\section{Data and Descriptive Statistics}

The data used in this paper are mainly taken from the 2001 Census for England and Wales. ${ }^{1}$ The primary reason for this is that large samples are required in order to examine the relationship between informal caring and labour market outcomes at a spatially disaggregated level. The Census provides us with this because in theory it collects information on all persons resident in the UK on a certain date. Not only is it then possible to examine aggregate statistics on care provision, labour market outcomes and other variables from the Census but analysis can also be undertaken using some microdata files that have been made available. The Sample of Anonymised Records (SARs) contains detailed socio-

${ }^{1}$ Similar, but separate, Censuses were undertaken at the same time in Scotland and Northern Ireland. Although some of the information can be directly compared across the three Census areas within the UK, there are some differences, so this paper will mainly concentrate on the data collected in England and Wales. 
economic information on a 3\% random sample of individuals completing Census forms. However, it is not possible to identify geographical areas below the regional level in the SARs, which constrains the analysis that it is possible. Therefore, the dataset that is mainly used in this paper is the Small Area Microdata (SAM) file, which is a $5 \%$ random sample of Census returns that was specifically created to facilitate research at the sub-regional level. ${ }^{2}$ In particular, the SAM enables individuals to be identified at the Local Authority (LA) and Unitary Authority (UA) level. ${ }^{3}$ Another reason for using Census microdata is that there are no appropriate questions in the Labour Force Survey (LFS), which is the main regular source of information on socio-economic variables in the UK. ${ }^{4}$ The sample sizes available in other UK surveys that have been used to examine caring and labour market outcomes such as the GHS and BHPS are far too small to undertake detailed spatial analysis.

Of particular importance to this study is the question on informal care, which was asked in the Census for the first time in 2001. The precise wording of the question was "Do you look after, or give any help or support to family members, friends, neighbours or others because of long-term physical or mental ill-health or disability or problems related to old age?". The information on carers from the Census has been analysed in several different contexts. These include an initial analysis of aggregate data on caring for the whole of the UK by Doran et al. (2003). Shaw and Dorling (2004) also use aggregate Census data to report a positive relationship between informal care provision and health need at the UA/LA level in England and Wales. Buckner and Yendle (2006) examine both aggregate Census data and the SARs to construct a picture of caring in England and Wales, including identifying the main characteristics of carers. Del Bono et al. (2009) analyse gender differences in care provision in the UK using the SARs and report that caring is far higher for females but that the differential varies considerably across the lifecycle and according to marital status. Norman and Purdham (2010) analyse the SAM for Primary Care Trusts in England and Wales (which are built up from LAs/UAs). They report large geographical

\footnotetext{
${ }^{2}$ The SAM was released in 2007. An equivalent file from the 2011 Census is unlikely to be available for several years.

${ }^{3}$ LAs and UAs are the local government areas in England and Wales and are the providers of local services. There are no real differences between LAs and UAs for the purposes of this paper, although local government areas in England and Wales do differ in size, both in terms of area and population. See Table A1 for an indication of some of the demographic variations.

${ }^{4}$ The LFS does not contain information at the sub-regional level but identifiers for UAs and LAs are available in the Annual Population Survey (APS), which collects similar information but again not on the provision of care. Even if it did, samples are still much smaller in the APS than they are in the SAM.
} 
differences in care provision, including for different demographic groups, and depending on whether the care takes place within or outside of the household.

With respect to the SAM, two variables have been created from the responses to this question. The first is a banded question on time spent per week caring and a second on the number of carers in the household. Since the Census also collects a range of other socioeconomic information at the individual and household level, it is possible to use the SAMS to undertake a range of analysis. Given the focus of this study, we are particularly interested in the labour market variables. Although the SAM contains information on the labour market characteristics of individuals, the level of detail on some of the variables has been suppressed (for confidentiality reasons) because of the finer level of geographical disaggregation available in this data file. For example, responses to the question on the individual's main economic activity have been grouped into four categories (employed, selfemployed, unemployed and inactive). Other socio-economic variables have also been combined such as age (generally into 5 year age bands) and ethnicity (only 5 groups identifiable: White, Black, Asian, Chinese/Other Asian and Other). Information on usual hours of work has been banded into five categories (1-15, 16-30, 31-37, 38-48 and 49 or more hours). Limited information is available on an individual's occupation (split into eight categories using the National Statistics Socio-Economic Classification) but no earnings or income questions are asked in the UK Census. The SAM also contains some basic household level information.

Despite the 2001 Census now being rather dated, Table 1 shows that the analysis of these data is still very relevant, especially as the differences are not that great between the LFS and Census for inactivity and employment statistics. ${ }^{5}$ The table also shows the very large sample size afforded by the SAM in comparison to a single quarter of LFS data. For example, there are almost 900,000 males in the sample of SAM data used to calculate employment and inactivity rates, compared to just over 30,000 in the LFS. There are some differences in the labour market statistics provided by the Census and the LFS, with Heap (2005) suggesting that there was higher employment in the LFS in 2001. Interestingly though, inactivity and employment rates are similar in 2001 and 2010, especially for males. In fact, the UK male employment rate in the 2001 Census was identical to that seen in the LFS in the second quarter of 2010. For females, there has been an increase in employment and a decrease in inactivity rates. The regional rankings are also pretty much unchanged, with the highest male inactivity rates seen in Wales in both years. Inactivity is also relatively high for Welsh females but female inactivity rates are highest in Northern Ireland in both

\footnotetext{
${ }^{5}$ Inactive students have been removed from the calculation of inactivity and employment rates.
} 
years. Given that there is no question on informal caring in the LFS, the Census continues to provide the most recent information on this at the sub-national level. However, Bell (2010) using information from the Family Resources Survey reports that there has been a decline in the proportion of adults providing care in all parts of the UK, with some convergence between its constituent countries. As was the case for labour market inactivity, the provision of informal caring is found to be highest for males in Wales, and Welsh females are second only to those living in Northern Ireland in this respect.

Table A1 reports health, caring and labour market statistics in LAs and UAs in England and Wales in 2001 using aggregate information from the Census. The table reports the top and bottom 20 UAs/LAs ranked by the percentage providing informal care. Using the information in Tables 1 and A1 allows us to identify a number of areas within England and Wales on the basis of their incidence of caring. These are the London, East and South East (LESE), the Rest of England (ROE), the SWV and the Rest of Wales (ROW). The area that the SWV covers is not generally defined according to administrative boundaries but given that finest level of geography available in the SAM is LAs/UAs, these need to be used in order to construct such an area. The seven UAs included in the SWV are Blaenau Gwent, Bridgend, Caerphilly, Merthyr Tydfil, Neath Port Talbot, Rhondda Cynon Taff and Torfaen. ${ }^{6}$ It can be seen from Table A1 that all seven of the UAs in the SWV are located in the top twelve districts in terms of having the highest levels of informal care in England and Wales (348 in total). Table A1 also shows that employment was generally much lower and inactivity much higher in UAs within the SWV. An important factor in this is poor health in this area and the SAM provides evidence of this by showing that the incidence of limiting long term illness, as well as self-reported poor health, was much higher in Wales compared to the UK average (Table 1) and in the SWV in particular (Table A1).

Table 2 reports some descriptive statistics relating the amount of care provided in the English regions and areas within Wales. It can be seen that caring was highest both amongst males and females in the SWV. In 2001, $14.0 \%$ and $18.4 \%$ of working age males and females living in the SWV provided informal care. In the ROW, the equivalent percentages were $11.8 \%$ and $14.3 \%$ and in London they were $8.7 \%$ and $11.5 \%$. The percentage providing large amounts of care was also much higher in the SVW, with $3.2 \%$ and $4.8 \%$ of working age males and females providing 50 or more hours of informal care each week, compared to $1.2 \%$ of males and just over $2 \%$ of females in London. The number of carers in the household was also higher in the SWV, with $18.3 \%$ of households having a

\footnotetext{
${ }^{6}$ Parts of Carmarthenshire and Swansea also tend to be included in the area that is typically thought to cover the SWV but the majority of the populations of these two UAs lies outside of these valleys.
} 
single carer and $10.0 \%$ two or more carers. The equivalent percentages for London were $11.4 \%$ and $6.2 \%$.

With regards to background labour market statistics for the four specified areas of England and Wales, Table 3 displays inactivity rates, employment rates and the percentage of part-timers for both males and females. Although inactivity rates were much higher for males in the SVW, they were particularly high for male carers of working age, with over $60 \%$ of those providing 50 or more hours of care not in the labour force. This also translated into lower employment rates since only a third of males from the SWV in this category were in work. Female inactivity rates were highest in the ROW, with $68 \%$ of working age females in the higher care category in the ROW being inactive. However, the differentials for females in the SWV were not that large relative to other parts of the UK. The percentage of workers who were part-time was low for males in each of the areas, and did not vary much by the amount of care provided. In fact, part-time rates for males were lowest in the SWV, where well under $10 \%$ of males worked part-time, even if they provided at least 50 hours of care, which was 2-3 percentage points lower than in the other areas. For females, although the percentage of part-timers was much higher and the increase in part-time work rose more sharply with the amount of care provided than it did for males, the spatial pattern is less clear. It was actually in the ROE where intensive providers of care were most likely to be part-time, with around $60 \%$ of those providing at least 50 hours of care working part-time, compared to $57 \%$ in LESE, 55\% in the SWV and 51\% in the ROW.

Table A2 provides additional details on the weekly hours of work of carers and noncarers by reporting the distribution of hours of work by area. It shows that for both males living in the SVW who were in work tended to work fairly long hours. For example, only a very small proportion of males in the SWV worked less than 16 hours a week regardless of the amount of care they provided. Males providing an intensive level of care in this part of Wales also often had long working hours, with around a quarter of those reporting that they cared for more than 50 hours a week also supplying over 48 hours of paid work, which was the highest of all of the care categories in the SWV. There are not great differences between the other areas for males, whilst over $20 \%$ of female intensive providers of care in each area worked less than 16 hours per week.

\section{Econometric Modelling}

A series of probit models are estimated in order to examine the relationship between informal care provision and labour market outcomes. The econometric investigation that follows has been guided by the discussion and descriptive analysis from the preceding sections. For example, attention is focused on employment rather than participation in the labour market. The models have also been estimated separately for males and females. This 
contrasts with Heitmueller (2007) who estimates a joint model for males and females, whereas Carmichael and Charles (2003) also estimate separate models. Given the importance of part-time employment for females, especially for carers, estimates are also reported for the impact of care on whether the worker was employed for less than 30 hours a week. With respect to the measure of care that is used, an indicator is included in the models for whether the individual reported that they provided 20 or more hours of care per week. This has been done not just because of the way in which the caring variable in the Census has been banded but also due to the clear distinction in labour market outcomes for those providing at least 20 hours of care revealed in the descriptive analysis in the previous section, as well as by Carmichael and Charles (1998).

Due to the possible co-determination of caring and labour market activities, studies have used various econometric techniques in an attempt to address the problems that might arise from this. Dealing with potential endogeneity issues is not straightforward using a dataset such as the SAM because it is a single cross-section and does not contain a wide selection of variables that could be used as suitable instruments. In contrast, Heitmueller (2007) makes use of both the time dimension of the BHPS and access to a wider range of potential instruments to estimate IV probit models of labour market participation. However, one drawback of this approach is that it is more difficult to interpret and compare the results obtained from IV probit models. For example, Heitmueller (2007) notes that the use of instruments increases the coefficient measuring the impact of caring on the probability of employment. ${ }^{7}$ There are also more general criticisms of IV estimates when the correlation between the potentially endogenous variables and instruments is weak. In particular, Bound et al. (1995) suggest that the use of IV techniques in such circumstances can produce large inconsistencies in the estimates. This can even be the case in data sets with a large number of observations, like the SAM. As a result, they conclude that valid instruments are difficult to find and that the use of inappropriate instruments can do more harm than good.

In terms of the other explanatory variables, similar regressors have been included to those used by Carmichael and Charles $(1998,2003)$ and Heitmueller (2007). In particular controls have been added for age, health, marital status, ethnic group, qualifications, household size, dependent children and housing tenure. The impact of each of the explanatory variables is reported in the tables as marginal effects. These give the change in the probability of the event (in this case employment) between two categories, such as

\footnotetext{
${ }^{7}$ The standard errors of the estimates are also inflated, lowering the associated z-statistics in the IV probits estimated by Heitmueller (2007) compared to the conventional probits.
} 
between the dummy variable in question and the default category, holding all other factors in the model constant. The marginal effects are calculated at sample means.

Several different sets of models are estimated in the econometric analysis. As a starting point, a set of pooled models is estimated for employment outcomes in England and Wales, which include the area-level variables and the care indicator, so that the basic type of model that is estimated is:

$$
E_{i}^{*}=x_{i}^{\prime} \beta+\delta_{j} \sum_{j=1}^{3} A_{i}+\gamma C_{i}+u_{i}
$$

where $x_{i}$ is a vector of explanatory variables, $\beta$ a vector of associated coefficients and $u_{i}$ a standard normal random error term. $A_{i}$ contains a set of three area dummy variables (specifically controls for living in LESE, the ROE and the ROW and is measured relative to the SWV) and $\delta_{j}$ their associated coefficients. $C_{i}$ is a binary variable taking the value of 0 if the individual provides less than 20 hours of informal care per week and a value of 1 if they provide 20 or more hours, with its associated coefficient represented by $\gamma$. The binary dependent variable indicating whether the individual is employed (or whether they work parttime) is defined as follows:

$$
\begin{aligned}
& E_{i}=1 \text { if } E_{i}^{*} \geq 0, \text { the individual is in employment } \\
& E_{i}=0 \text { otherwise, the individual is out of employment. }
\end{aligned}
$$

The next set of models is estimated separately for males and females in the four areas (denoted by the $\mathrm{j}$ subscript) and we are particularly keen to observe how the $\gamma$ coefficient, reported by a marginal effect in the results, varies by area. This implies that the second set of models that is estimated becomes:

$$
E_{i j}^{*}=x_{i j}^{\prime} \beta_{j}+\gamma_{j} C_{i j}+u_{i j}
$$

It is also of interest to establish whether the characteristics of those who are employed in the four different areas varies according to the amount of care that they provide and also whether there are differences between the areas. Therefore, the final set of models is estimated separately by gender in each area and the estimates are also reported according to whether or not the individual provides the threshold ( 20 hours per week) level of care:

$$
E_{i j c}^{*}=x_{i j c}^{\prime} \beta_{j c}+u_{i j c}
$$




\section{Results}

Table 4 contains marginal effects and standard errors from three sets of probit models for employment outcomes that have been estimated for males and females. A set of estimates for the probability of having a job is reported separately for males and females, whilst another set of estimates relates to the factors determining whether or not females are employed on a part-time basis. The first point to note from the table is that the impact of the care dummy on the probability of employment is pretty similar for males and females, with the employment rate for males and females providing an intensive level of care being respectively around 18 and 20 percentage points lower than comparable individuals who do not. There are significant employment differences by area, with the lowest employment rates for males found in the SWV in 2001. The difference with respect to the other areas was around 9 percentage points compared to the LESE, 6 percentage points to the ROE and 3 percentage points compared to the ROW. Employment rates were also lower for females in the SWV, with a slightly smaller differential observed relative to the English areas in comparison to males.

The other estimates in the table are consistent with expectations and other empirical studies of employment. For example, employment rates are by far the lowest in the highest working age category: 60-64 for males and 50-59 for females. Education exerts a strong positive effect on employment probabilities, particularly for females. There are also large ethnic differences, with significantly lower employment rates observed for males and females in each of the ethnic minority groups. Health has a very strong effect, particularly for males with those reporting that their health was not good around 50 percentage points less likely to be in employment compared to males reporting good health. The presence of dependent children also significantly reduces employment for females. Female workers providing at least 20 hours of care per week were around 7 percentage points more likely to be employed on a part-time basis. In contrast to the employment estimates, females in the SWV were the least likely to work part-time after controlling for other characteristics. The probability of parttime employment for females is highest for the youngest and oldest workers, white, those with no qualifications and for married mothers with dependent children.

Table 5 reports estimates for the impact of providing intensive levels of care on employment for the four different areas. It can be seen the marginal effect of this care dummy on the probability of employment is very similar in the four areas since individuals were approximately 20 percentage points less likely to have a job compared to those who provide less than 20 hours of care in each of the four areas. There are, however, greater spatial variations in the influence of care on both male employment probabilities and on parttime work for females, with in both cases the impact being largest in the SWV. In particular, 
males in the SWV who were intensive providers of care were 22 percentage points less likely to be in employment, which as well as being three percentage points higher than that observed in the ROE and ROW is also higher than the relative effect seen for females in the SWV. The smallest effect of caring on the probability of employment occurs for males in LESE. The impact of intensive caring on part-time employment for females was also highest in the SWV, with the marginal effect of this variable around a percentage point above that obtained in the two areas of England and over four percentage points greater than in the ROW.

Tables 6, 7 and 8 contain marginal effects for each of the explanatory variables in the models from estimating equation (3) for the probability of being in employment separately for males and females and then for the probability of part-time work for females. The estimates for those providing less than 20 hours of care appear on the left hand side of each table, whilst the equivalent information for intensive providers of care is shown on the right hand side. The impact of the explanatory variables is generally of the same sign and of a similar magnitude in each of the areas, although there are some variations in these according to particular care category. It should be noted though that the sample sizes for the two Welsh areas, in particular the SWV, are quite small for intensive providers of care. Table A3 in the Appendix contains the mean values of the explanatory variables for males and females in each of the four areas. Average characteristics also tend to be fairly similar across areas, although there are some differences worth highlighting including the relatively high (low) levels of people with no (degree) qualifications in the SWV. The percentage reporting that they are not in good health is also relatively high in this area, whereas only 1 per cent of the working age population in the SWV is non-white. This has an impact on the explanatory variables that can be included in these models since the small number of ethnic minority individuals in the sample for the SWV means that ethnic controls are excluded.

Several features are noticeable from Table 6 with reference to the probability of employment for males. Again many of these pertain to the SWV including the large positive effect of qualifications on employment for those providing less than 20 hours of care. In addition, the estimates reveal that amongst this care category, the strongest negative employment effects are observed in the SVW for 60-64 year old males and those reporting that they were not in good health. As noted above, the number of observations in the model estimated for intensive providers of care is much smaller and this means that many of the marginal effects for the explanatory variables are not statistically significant. However, a strongly negative employment effect is found for males providing at least 20 hours of care per week living in large households in the SWV, whereas this effect is not apparent in the other areas. The very large non-employment rates for the 60-64 age group is again evident for this care category in the SWV, although the marginal effect is lower than it is in the ROW. 
The importance of qualifications for employment is also demonstrated for females in Table 7. This applies to both care categories and the magnitude of the marginal effects of having particular qualifications in comparison to none at all is greater than it is for males in all four areas. The comparison between the effect of qualifications for the two care categories by area is mixed, with it appearing stronger for intensive providers of care in England, and to some extent for the ROW, whereas some very large marginal effects are observed for females providing less than 20 hours of care in the SWV. As was the case for males, the negative employment impact of not being in good health is also highest in the SWV for this care category. Similarly, the reduction in the probability of employment for intensive older carers is again most noticeable in the SWV, with 50-59 year old females in this category having a 27 percentage point lower employment rate compared to 16-19 year old females. However, this effect is only significant at the 10 per cent level because of the small number of observations.

The impact of socio-economic characteristics on part-time employment for females is reported for the two care categories in Table 8. Amongst intensive providers of care, there are few significant effects for any of the areas. The exceptions to this are for qualifications, which again exert a very strong influence, and the presence of dependent children in the household. Ethnic dummies are also significant in LESE, with each of the ethnic minority groups significantly less likely to work on a part-time basis in comparison to whites. This is also true for Asians in the ROE, whereas cell sizes in this care category are small for the ethnic minority groups in the ROW. Although not generally significant, even at the $10 \%$ level, the sign on many of the age dummies for intensive providers of care is positive compared to the reference category of aged 16-19. This contrasts with the results for the other care category, where the 16-19 year old group is the most likely to work part-time in each of the areas and the differences are large apart from in comparison to 50-59 year olds.

\section{Conclusion}

In common with previous US and UK studies, involvement in the provision of informal care is found to be associated with much lower rates of labour market participation and employment for both males and females and with shorter working hours for females. However, this study has addressed the issue from a sub-national perspective, allowing variations to be identified between areas within a country. In particular, the main focus of this study is on an area which has high levels of caring, the South Wales Valleys. Although the descriptive analysis suggests that the relationship between caring and labour market activity is fairly similar to that which exists in other parts of England and Wales, despite having higher levels of informal caring, the econometric analysis reveals some interesting variations between areas. These include the larger relative impact of intensive caring on part-time employment for 
females in the South Wales Valleys. Providing high amounts of care also has the greatest impact on reducing the probability of employment for males in the South Wales Valleys, despite their lower overall employment rates. However, the descriptive statistics suggest that those males who provide large amounts of care in the South Wales Valleys also worked relatively long hours, with very few working less than 16 hours per week.

In terms of future research on this issue then it will be interesting to observe whether the patterns identified in this study have persisted. For example, these estimates relate to 2001, a time when the provision of informal caring was very high and the proportion of informal carers appears to have fallen across the UK since then (Bell, 2010). The availability of information from the 2011 Census in a couple of years should enable comparisons to be made with the position that prevailed in 2001, given the same question was asked on informal care provision. However, a drawback of the data that have been used is that although they are suited to examining the issue from a sub-national perspective, it is difficult to use them to deal with concerns connected to the possible endogeneity of informal caring. Therefore, it may prove tricky to address these concerns from a sub-national perspective even in the future because of the nature of the information normally included in Census microdata, unless additional data can be matched in.

The findings in this paper suggest that a freeing up of resources through the increased provision of formal care may have some beneficial effects for local labour markets. This is because of the indirect effect of ill-health since higher levels of informal care limit participation in the labour market. However, because of the current constraint on public sector budgets in the UK, the increase in such a resource is very unlikely. It is also unclear what effect future changes to the benefits system such as introduction of more formal testing and the continued replacement of incapacity benefit with the seemingly less favourable Employment Support Allowance, in an attempt to get claimants off benefits and into work, will have. For such policies to be effective then it is likely that there will be a simultaneous need for a significant amount of job creation in the most affected areas. For example, Beatty and Fothergill (2011) estimate that 70,000 extra jobs are needed in the South Wales Valleys to bring the employment rate up to those seen in the parts of the UK with the highest rates. Therefore, it would appear that focusing just on benefit reform, without any accompanying policies to boost labour demand, is unlikely to boost participation in areas with high levels of ill-health and informal care provision. Furthermore, if the government's austerity measures lead to cutbacks in formal care provision, the estimates reported in this paper would suggest there could be a further divergence in labour market outcomes between areas according to the levels of informal care that are provided. 


\section{References}

Arber, S. and Ginn, J. (1995), "Gender differences in the relationship between paid employment and informal care", Work, Employment and Society, 9, 445-71.

Beatty, C. and Fothergill, S. (2005), "The diversion from 'unemployment' to 'sickness' across British regions and districts", Regional Studies, 39, 837-54.

Beatty, C., Fothergill, S. and Powell, R. (2007), "Twenty years on: Has the economy of the UK coalfields recovered?", Environment and Planning A, 39, 1654-75.

Beatty, C. and Fothergill, S. (2011), Tackling Worklessness in Wales, Report to the Industrial Communities Alliance (Wales).

Bell, D. (2010), The Impact of Devolution: Long Term Care Provision in the UK, Report to the Joseph Rowntree Foundation.

Blackaby, D., Jones, M., Jones, R. Latreille, P., Murphy, P., O'Leary, N. and Sloane, P. (2003), Identifying Barriers to Economic Activity in Wales: Part I, Report to the Welsh Assembly Government.

Boaz, R. F. and Muller, C. F. (1992), "Paid work and unpaid help by caregivers of the disabled and frail elders", Medical Care, 30, 149-58.

Bolin, K., Lindgren, B. and Lundborg, P. (2008), "Your next of kin or your own career? Caring and working among the 50+ of Europe", Journal of Health Economics, 27, 718-38.

Bound, J., Jaeger, D. and Baker, R. (1995), "Problems with instrumental variables estimation when the correlation between the instruments and the endogeneous explanatory variable is weak", Journal of the American Statistical Association, 90, 443-50.

Buckner, L. and Yeandle, S. (2006), Working Carers: Evidence from the 2001 Census, Carers UK, London.

Carmichael, F. and Charles, S. (1998), "The labour market costs of community care", Journal of Health Economics, 17, 747-65.

Carmichael, F. and Charles, S. (2003), "The opportunity costs of informal care: Does gender matter?", Journal of Health Economics, 22, 781-803.

Del Bono, E., Sala, E., and Hancock, R. (2009), "Elderly carers in the UK: Are there really gender differences? New analysis of the Individual Sample of Anonymised Records from the 2001 UK Census", Health and Social Care in the Community, 17, 267-73.

Do, Y. K. (2008), "The effect of informal caregiving on labor market outcomes in South Korea", Asia Health Policy Program Working Paper No. 1.

Doran, T., Drever, F. and Whitehead, M. (2003), "Health of young and elderly informal carers: Analysis of UK Census data", British Medical Journal, 327 (7428), 1388.

Ettner, S. (1995), "The impact of 'parent care' on female labor supply decisions", Demography, 32, 63-80. 
Ettner, S. (1996), "The opportunity costs of elder care", Journal of Human Resources, 31, 189-205.

Fothergill, S. (2001), "The true scale of the regional problem in the UK", Regional Studies, 63, 241-6.

Heap, D. (2005), "Comparison of 2001 Census and LFS labour market indicators", Labour Market Trends, January, 33-48.

Heitmueller, A. (2007), "The chicken or the egg? Endogeneity in labour market participation of informal carers in England", Journal of Health Economics, 26, 536-59.

Jones, M. K. and Latreille, P. L. (2008), "A picture of the work and well-being of working age carers in Wales: Evidence from the Welsh Health Survey", Welsh Economic Review, 19(2), 35-9.

Leigh, A. (2010), "Informal care and labor market participation", Labour Economics, 17, 14049.

Maurer-Fazio, M., Connelly, R., Chen, L. and Tang, L. (2011), "Childcare, eldercare, and labor force participation of married women in urban China, 1982-2000." Journal of Human Resources, 46, 261-94.

Norman, P. and Purdham, K. (2010), "Geographical and social variations in unpaid caring within and outside the household in England and Wales", CCSR Working Paper 2010-03, University of Manchester.

O'Leary N., Murphy P. D., Latreille, P., Blackaby, D. H. and Sloane, P. J. (2005), "Accounting for differences in labour market outcomes in Great Britain: A regional analysis using the Labour Force Survey", IZA Discussion Paper No. 1501.

Pezzin, L. E. and Schone, B. (1999), "Intergenerational household formation, female labour supply and informal care giving", Journal of Human Resources, 34, 475-503.

Shaw, M. and Dorling, D. (2004), "Who cares in England and Wales? The positive care law: cross-sectional study", British Journal of General Practice, 54, 899-903.

Stone, I. R. and Farley-Short, P. (1990), "The competing demands of employment and informal caregiving to disabled elders", Medical Care, 28, 513-26.

Viitanen, T. (2010), "Informal elderly care across Europe: Estimates from the European Community Household Panel, Economic Analysis and Policy, 40, 149-78.

Wolf, D. A. and Soldo, B. J. (1994), "Married women's allocation of time to employment and care of elderly parents", Journal of Human Resources, 29, 1259-76. 
Table 1: Health, Caring and Employment by Region of the UK

\begin{tabular}{|c|c|c|c|c|c|c|c|c|c|c|c|c|}
\hline & \multirow{2}{*}{\multicolumn{2}{|c|}{$\begin{array}{l}\text { \% Long Term III } \\
\text { (2001) }\end{array}$}} & \multirow{2}{*}{\multicolumn{2}{|c|}{$\begin{array}{l}\text { \% Providing } \\
\text { Care (2001) }\end{array}$}} & \multicolumn{4}{|c|}{ Inactivity Rate } & \multicolumn{4}{|c|}{ Employment Rate } \\
\hline & & & & & \multicolumn{2}{|c|}{ Male } & \multicolumn{2}{|c|}{ Female } & \multicolumn{2}{|c|}{ Male } & \multicolumn{2}{|c|}{ Female } \\
\hline & Male & Female & Male & Female & 2001 & 2010 & 2001 & 2010 & 2001 & 2010 & 2001 & 2010 \\
\hline North East & 26.4 & 27.3 & 11.1 & 16.3 & 19.4 & 14.6 & 29.1 & 21.7 & 72.7 & 75.8 & 66.7 & 72.1 \\
\hline North West & 24.2 & 25.8 & 11.4 & 15.8 & 17.2 & 14.2 & 26.7 & 21.7 & 76.6 & 77.9 & 69.7 & 73.1 \\
\hline Yorks. \& Humb. & 22.5 & 24.4 & 10.9 & 15.1 & 15.1 & 12.9 & 26.0 & 20.1 & 78.7 & 77.3 & 70.3 & 73.9 \\
\hline East Midlands & 20.8 & 23.1 & 11.0 & 14.8 & 13.3 & 12.0 & 24.3 & 19.7 & 81.6 & 81.3 & 72.1 & 73.9 \\
\hline West Midlands & 21.2 & 24.1 & 11.2 & 15.4 & 14.3 & 11.7 & 26.3 & 22.9 & 79.5 & 79.4 & 69.8 & 71.6 \\
\hline East & 17.9 & 20.8 & 9.9 & 13.6 & 10.7 & 9.6 & 24.1 & 19.3 & 85.4 & 83.6 & 73.0 & 75.6 \\
\hline London & 17.4 & 19.3 & 8.8 & 11.5 & 13.3 & 10.9 & 26.3 & 24.4 & 79.6 & 80.9 & 68.9 & 68.2 \\
\hline South East & 17.0 & 19.7 & 9.5 & 13.0 & 10.3 & 9.9 & 23.0 & 18.7 & 86.0 & 84.2 & 74.4 & 76.6 \\
\hline South West & 20.0 & 22.5 & 10.0 & 13.9 & 12.5 & 11.4 & 23.2 & 18.7 & 83.4 & 82.6 & 73.9 & 76.6 \\
\hline Scotland & 22.7 & 25.3 & 9.8 & 14.4 & 16.7 & 14.1 & 25.6 & 19.9 & 76.7 & 77.4 & 70.5 & 74.1 \\
\hline Wales & 27.0 & 28.9 & 12.4 & 17.1 & 19.5 & 15.5 & 29.9 & 22.8 & 74.6 & 75.8 & 66.5 & 71.4 \\
\hline Northern Ireland & 23.1 & 26.4 & 11.9 & 17.8 & 18.3 & 14.9 & 31.9 & 25.5 & 74.6 & 77.3 & 64.3 & 71.6 \\
\hline UK & 20.9 & 23.2 & 10.4 & 14.3 & 14.2 & 12.1 & 25.7 & 21.0 & 80.1 & 80.1 & 70.7 & 73.3 \\
\hline$N$ & 1124670 & 1219754 & 929562 & 874833 & 880236 & 31061 & 824817 & 29985 & 880236 & 31061 & 824817 & 29985 \\
\hline
\end{tabular}

Notes: The sample used to calculate the percentage with a long term illness is the population over 16 . The sample used to calculate the percentage providing care, employment and inactivity rates is the working age population (16-59/64). Inactive students have been excluded from the sample used to calculate the inactivity and employment rates. The statistics from the LFS are based on weighted data. 
Table 2: Provision of Informal Care by the Working Age Population in England and Wales, 2001

\begin{tabular}{|c|c|c|c|c|c|c|c|c|c|c|c|}
\hline & \multicolumn{8}{|c|}{ Weekly hours of care provided (\% in each category) } & \multirow{2}{*}{\multicolumn{3}{|c|}{$\begin{array}{l}\text { Number of Carers in the } \\
\text { Household (\% in each category) }\end{array}$}} \\
\hline & \multicolumn{4}{|c|}{ Males } & \multicolumn{4}{|c|}{ Females } & & & \\
\hline & 0 & $1-19$ & $20-49$ & $50+$ & 0 & $1-19$ & $20-49$ & $50+$ & 0 & 1 & 2 or more \\
\hline North East & 88.8 & 7.6 & 1.4 & 2.2 & 83.7 & 10.6 & 2.2 & 3.5 & 76.1 & 15.8 & 8.1 \\
\hline North West & 88.7 & 8.1 & 1.3 & 2.0 & 84.2 & 10.7 & 2.1 & 3.0 & 76.7 & 15.0 & 8.4 \\
\hline Yorkshire \& Humberside & 89.1 & 7.9 & 1.2 & 1.8 & 84.9 & 10.3 & 1.9 & 2.9 & 77.8 & 14.0 & 8.2 \\
\hline East Midlands & 89.0 & 8.2 & 1.1 & 1.6 & 85.2 & 10.5 & 1.7 & 2.5 & 78.6 & 13.0 & 8.4 \\
\hline West Midlands & 88.8 & 8.1 & 1.2 & 1.9 & 84.7 & 10.5 & 1.9 & 3.0 & 77.5 & 13.8 & 8.7 \\
\hline East & 90.1 & 7.8 & 0.9 & 1.2 & 86.4 & 10.1 & 1.3 & 2.2 & 80.3 & 12.2 & 7.6 \\
\hline London & 91.3 & 6.5 & 1.1 & 1.2 & 88.5 & 7.9 & 1.5 & 2.2 & 82.4 & 11.4 & 6.2 \\
\hline South East & 90.5 & 7.6 & 0.7 & 1.2 & 87.0 & 9.8 & 1.2 & 2.0 & 81.3 & 11.4 & 7.3 \\
\hline South West & 90.0 & 7.7 & 0.9 & 1.2 & 86.1 & 10.0 & 1.5 & 2.5 & 80.1 & 12.4 & 7.6 \\
\hline England & 89.7 & 7.7 & 1.0 & 1.6 & 85.9 & 9.9 & 1.6 & 2.6 & 79.4 & 13.0 & 7.7 \\
\hline South Wales Valleys & 86.0 & 9.0 & 1.8 & 3.2 & 81.6 & 10.8 & 2.7 & 4.8 & 71.8 & 18.3 & 10.0 \\
\hline Rest of Wales & 88.2 & 8.2 & 1.4 & 2.2 & 83.4 & 10.7 & 2.2 & 3.7 & 75.9 & 15.2 & 8.9 \\
\hline Wales & 87.7 & 8.4 & 1.5 & 2.5 & 83.0 & 10.7 & 2.3 & 4.0 & 74.9 & 16.0 & 9.2 \\
\hline
\end{tabular}


Table 3: Labour Market Outcomes and Informal Care Provision Category, 2001

\begin{tabular}{lcccccccccc}
\hline & \multicolumn{4}{c}{ Males } & & \multicolumn{4}{c}{ Females } \\
\cline { 2 - 4 } \cline { 9 - 11 } & LESE & ROE & SWV & ROW & & LESE & ROE & SWV & ROW \\
\hline Inactivity Rate: 0 hours of care & 10.2 & 14.2 & 23.1 & 16.8 & & 23.4 & 24.5 & 33.7 & 26.4 \\
Inactivity Rate: 1-19 hours caring & 12.5 & 14.6 & 18.8 & 15.8 & & 23.4 & 22.2 & 28.6 & 23.9 \\
Inactivity Rate: 20-49 hours caring & 23.4 & 30.1 & 38.8 & 32.6 & & 41.0 & 43.5 & 49.8 & 42.7 \\
Inactivity Rate: 50+ hours caring & 41.8 & 52.2 & 60.7 & 51.9 & & 62.5 & 63.6 & 68.0 & 62.4 \\
\hline Employment Rate: 0 hours of care & 84.2 & 79.9 & 70.4 & 77.3 & & 73.1 & 71.7 & 62.1 & 69.9 \\
Employment Rate: 1-19 hours caring & 83.4 & 80.8 & 75.9 & 79.7 & & 73.6 & 74.9 & 68.6 & 73.6 \\
Employment Rate: 20-49 hours caring & 69.5 & 63.3 & 56.5 & 61.3 & & 55.5 & 53.5 & 47.5 & 54.2 \\
Employment Rate: 50+ hours caring & 53.5 & 42.9 & 33.3 & 43.8 & & 35.6 & 34.6 & 30.5 & 35.7 \\
\hline Part-time Rate: 0 hours of care & 8.8 & 8.8 & 7.1 & 9.7 & & 36.6 & 43.1 & 40.8 & 43.1 \\
Part-time Rate: 1-19 hours caring & 10.8 & 9.9 & 6.5 & 10.2 & & 45.4 & 47.8 & 44.2 & 46.9 \\
Part-time Rate: 20-49 hours caring & 11.1 & 11.2 & 7.6 & 10.3 & & 46.6 & 53.3 & 48.9 & 51.7 \\
Part-time Rate: 50+ hours caring & 10.9 & 11.8 & 8.1 & 10.9 & & 57.1 & 59.8 & 55.1 & 51.2 \\
\hline \hline
\end{tabular}


Table 4: Estimates from Probit Models of Employment

\begin{tabular}{|c|c|c|c|c|c|c|}
\hline & \multicolumn{4}{|c|}{ Employment } & \multirow{2}{*}{\multicolumn{2}{|c|}{$\begin{array}{l}\text { Part-time } \\
\text { females }\end{array}$}} \\
\hline & \multicolumn{2}{|c|}{ Males } & \multicolumn{2}{|c|}{ Females } & & \\
\hline & M.E. & S.E. & M.E. & S.E. & M.E. & S.E. \\
\hline $20+$ hours of care & -0.177 & 0.004 & -0.203 & 0.003 & 0.073 & 0.005 \\
\hline LESE & 0.089 & 0.003 & 0.048 & 0.004 & 0.030 & 0.007 \\
\hline ROE & 0.061 & 0.003 & 0.055 & 0.004 & 0.054 & 0.007 \\
\hline ROW & 0.033 & 0.003 & 0.031 & 0.005 & 0.050 & 0.008 \\
\hline Aged 20-24 & 0.054 & 0.002 & -0.081 & 0.004 & -0.143 & 0.004 \\
\hline Aged 25-29 & 0.079 & 0.002 & -0.076 & 0.003 & -0.194 & 0.003 \\
\hline Aged 30-39 & 0.083 & 0.002 & -0.052 & 0.003 & -0.143 & 0.003 \\
\hline Aged $40-49$ & 0.075 & 0.002 & 0.008 & 0.003 & -0.146 & 0.003 \\
\hline Aged 50-59 & 0.013 & 0.002 & -0.162 & 0.004 & 0.002 & 0.004 \\
\hline Aged 60-64 & -0.206 & 0.004 & _ & _ & _ & _ \\
\hline Level 1 qualifications & 0.065 & 0.001 & $0 . \overline{1} 20$ & $0 . \overline{001}$ & -0.074 & $0 . \overline{0} 02$ \\
\hline Level 2 qualifications & 0.073 & 0.001 & 0.161 & 0.001 & -0.108 & 0.002 \\
\hline Level 3 qualifications & 0.079 & 0.001 & 0.177 & 0.001 & -0.123 & 0.003 \\
\hline Level $4 / 5$ qualifications & 0.088 & 0.001 & 0.197 & 0.001 & -0.214 & 0.002 \\
\hline Other qualifications & 0.062 & 0.001 & 0.101 & 0.002 & -0.066 & 0.004 \\
\hline Mixed & -0.105 & 0.006 & -0.073 & 0.006 & -0.024 & 0.008 \\
\hline Asian & -0.112 & 0.003 & -0.187 & 0.003 & -0.097 & 0.004 \\
\hline Black & -0.124 & 0.004 & -0.024 & 0.004 & -0.095 & 0.005 \\
\hline Chinese \& Other & -0.099 & 0.006 & -0.134 & 0.006 & -0.077 & 0.008 \\
\hline Married & 0.073 & 0.001 & -0.035 & 0.001 & 0.144 & 0.002 \\
\hline Dependent children & 0.022 & 0.001 & -0.151 & 0.001 & 0.312 & 0.002 \\
\hline Fairly good health & -0.100 & 0.001 & -0.090 & 0.001 & 0.020 & 0.002 \\
\hline Not good health & -0.502 & 0.002 & -0.436 & 0.002 & 0.041 & 0.004 \\
\hline Owns house & 0.137 & 0.001 & 0.193 & 0.001 & -0.054 & 0.002 \\
\hline $5+$ in household & -0.029 & 0.002 & -0.054 & 0.002 & 0.045 & 0.002 \\
\hline Pseudo R-squared & \multicolumn{2}{|c|}{0.252} & \multicolumn{2}{|c|}{0.175} & \multicolumn{2}{|c|}{0.106} \\
\hline Number of observations & \multicolumn{2}{|c|}{768125} & \multicolumn{2}{|c|}{723880} & \multicolumn{2}{|c|}{622666} \\
\hline
\end{tabular}

Notes: Table reports marginal effects calculated at sample means and heteroscedasticity consistent standard errors. Default categories are lives in SWV, aged 16-19, no qualifications, white, unmarried, no dependent children, general health is good, does not own house and lives in a household with less than 5 people. 
Table 5: Probit Estimates of Intensive Levels of Care Provision on Employment by Area

\begin{tabular}{|c|c|c|c|c|c|c|c|c|c|c|c|c|}
\hline & \multicolumn{8}{|c|}{ Employment } & \multirow{2}{*}{\multicolumn{4}{|c|}{ Part-time Females }} \\
\hline & \multicolumn{4}{|c|}{ Male } & \multicolumn{4}{|c|}{ Female } & & & & \\
\hline & M.E. & S.E. & Pseudo $\mathrm{R}^{2}$ & $\mathbf{N}$ & M.E. & S.E. & Pseudo $\mathrm{R}^{2}$ & $\mathbf{N}$ & M.E. & S.E. & Pseudo $\mathrm{R}^{2}$ & $\mathbf{N}$ \\
\hline LESE & -0.147 & 0.006 & 0.215 & 306788 & -0.195 & 0.005 & 0.151 & 292610 & 0.076 & 0.008 & 0.147 & 211144 \\
\hline ROE & -0.194 & 0.005 & 0.267 & 419753 & -0.208 & 0.004 & 0.193 & 392114 & 0.074 & 0.006 & 0.118 & 277178 \\
\hline SVW & -0.224 & 0.026 & 0.347 & 11043 & -0.207 & 0.021 & 0.268 & 10406 & 0.085 & 0.031 & 0.108 & 6333 \\
\hline ROW & -0.192 & 0.017 & 0.281 & 30541 & -0.205 & 0.013 & 0.201 & 28750 & 0.041 & 0.019 & 0.095 & 19731 \\
\hline
\end{tabular}

Notes: Table reports marginal effects using sample means and heteroscedasticity consistent standard errors. Models also include controls for age, qualifications, ethnic group, marital status, dependent children, general health, home ownership and size of household. 
Table 6: Marginal Effects for the Probability of Employment for Males by Area

\begin{tabular}{|c|c|c|c|c|c|c|c|c|}
\hline & \multicolumn{4}{|c|}{ Provides less than 20 hours of Care } & \multicolumn{4}{|c|}{ Provides at least 20 hours of care } \\
\hline & LESE & ROE & SWV & ROW & LESE & ROE & SWV & ROW \\
\hline Aged 20-24 & $0.046^{\star \star \star}$ & $0.055^{\star \star \star}$ & $0.069^{\star \star \star}$ & $0.066^{\star \star \star}$ & 0.080 & 0.046 & 0.094 & -0.047 \\
\hline Aged 25-29 & $0.069^{\star \star \star}$ & $0.079^{\star \star \star}$ & $0.111^{\star \star \star}$ & $0.106^{\star \star *}$ & 0.085 & 0.014 & 0.236 & -0.192 \\
\hline Aged 30-39 & $0.070^{\star \star \star}$ & $0.088^{\star \star \star}$ & $0.112^{\star \star \star}$ & $0.109^{\star \star \star}$ & 0.048 & 0.011 & 0.023 & -0.074 \\
\hline Aged $40-49$ & $0.059^{\star \star \star}$ & $0.083^{* \star \star}$ & $0.125^{\star \star \star}$ & $0.101^{\star \star \star}$ & 0.056 & 0.015 & -0.005 & -0.042 \\
\hline Aged $50-59$ & $0.009^{\star \star \star}$ & $0.018^{\star \star \star}$ & 0.023 & 0.010 & -0.046 & $-0.078^{*}$ & -0.151 & $-0.217^{*}$ \\
\hline aged $60-64$ & $-0.185^{\star * *}$ & $-0.212^{\star \star \star}$ & $-0.299^{\star * \star}$ & $-0.236^{\star \star \star}$ & $-0.275^{\star * *}$ & $-0.297^{\star \star \star}$ & $-0.315^{\star \star \star}$ & $-0.373^{\star \star \star}$ \\
\hline Level 1 qualifications & $0.053^{\star \star \star}$ & $0.068^{\star \star \star}$ & $0.106^{\star \star \star}$ & $0.069^{\star \star \star}$ & $0.104^{\star \star \star}$ & $0.129^{\star \star \star}$ & 0.070 & $0.121^{\star *}$ \\
\hline Level 2 qualifications & $0.057^{\star \star \star}$ & $0.077^{\star \star \star}$ & $0.125^{\star \star \star}$ & $0.086^{\star \star \star}$ & $0.119^{\star \star \star}$ & $0.167^{\star \star \star}$ & 0.207 & $0.116^{\star *}$ \\
\hline Level 3 qualifications & $0.060^{\star \star \star}$ & $0.088^{\star \star \star}$ & $0.155^{\star \star \star}$ & $0.090^{\star \star \star}$ & $0.125^{\star \star \star}$ & $0.187^{\star \star \star}$ & 0.041 & 0.104 \\
\hline Level $4 / 5$ qualifications & $0.078^{\star \star \star}$ & $0.086^{\star * \star}$ & $0.128^{\star \star \star}$ & $0.098^{* \star *}$ & $0.127^{\star \star \star}$ & $0.163^{\star \star \star}$ & 0.127 & $0.117^{* *}$ \\
\hline Other qualifications & $0.053^{\star \star \star}$ & $0.062^{\star \star \star}$ & $0.099^{\star \star \star}$ & $0.068^{\star \star \star}$ & $0.096^{\star \star \star}$ & $0.135^{\star \star \star}$ & $0.152^{\star \star}$ & $0.154^{\star \star \star}$ \\
\hline Mixed & $-0.107^{\star \star \star}$ & $-0.100^{\star \star \star}$ & _- & $-0.069^{*}$ & -0.030 & -0.016 & - & -0.052 \\
\hline Asian & $-0.097^{\star \star \star}$ & $-0.130^{\star \star \star}$ & - & -0.029 & $-0.070^{\star \star \star}$ & $-0.070^{\star \star \star}$ & - & -0.061 \\
\hline Black & $-0.130^{\star \star \star}$ & $-0.097^{\star \star \star}$ & & $-0.101^{*}$ & 0.035 & 0.033 & - & -0.232 \\
\hline Chinese \& Other & $-0.103^{\star \star \star}$ & $-0.090^{\star \star \star}$ & & 0.024 & $-0.115^{\star \star}$ & 0.015 & - & 0.207 \\
\hline Married & $0.061^{\star \star \star}$ & $0.078^{\star \star \star}$ & $0.104^{\star \star \star}$ & $0.090^{\star \star \star}$ & $0.087^{\star \star \star}$ & $0.105^{\star \star \star}$ & -0.018 & $0.102^{\star *}$ \\
\hline Dependent children & $0.016^{\star \star \star}$ & $0.026^{\star \star \star}$ & $0.034^{\star \star \star}$ & $0.022^{\star \star \star}$ & $0.029^{\star}$ & $0.023^{*}$ & $0.113^{* *}$ & 0.031 \\
\hline Fairly good health & $-0.076^{\star \star \star}$ & $-0.106^{\star \star \star}$ & $-0.234^{* \star *}$ & $-0.156^{\star * \star}$ & $-0.113^{\star \star \star}$ & $-0.146^{\star \star \star}$ & -0.077 & $-0.276^{\star \star \star}$ \\
\hline Not good health & $-0.450^{\star \star \star}$ & $-0.525^{\star \star \star}$ & $-0.644^{* \star *}$ & $-0.579^{\star \star \star}$ & $-0.409^{\star \star \star}$ & $-0.407^{\star \star \star}$ & $-0.428^{\star \star \star}$ & $-0.396^{\star \star \star}$ \\
\hline Owns house & $0.097^{\star \star \star}$ & $0.155^{\star \star \star}$ & $0.231^{\star \star \star}$ & $0.152^{\star \star \star}$ & $0.258^{\star \star \star}$ & $0.333^{\star \star *}$ & $0.273^{\star \star \star}$ & $0.244^{\star \star \star}$ \\
\hline $5+$ in household & $-0.023^{\star \star \star}$ & $-0.032^{\star \star \star}$ & $-0.065^{* * *}$ & $-0.017^{* *}$ & -0.005 & -0.019 & $-0.177^{* * *}$ & $-0.097^{*}$ \\
\hline Pseudo R-squared & 0.210 & 0.260 & 0.344 & 0.278 & 0.174 & 0.214 & 0.267 & 0.190 \\
\hline Number of observations & 300131 & 406613 & 10465 & 29387 & 6657 & 13140 & 578 & 1154 \\
\hline
\end{tabular}

Notes: Default categories are lives in SWV, aged 16-19, no qualifications, white, unmarried, no dependent children, general health is good, does not own house and lives in a household with less than 5 people. Marginal effects have been calculated at sample means. ${ }^{*} p<0.1 ;{ }^{* k} p<0.05 ;{ }^{* * *} p<0.01$ (two-tailed tests). Ethnic controls excluded from models estimated for the SWV due to small number of ethnic minority individuals in this area. 
Table 7: Marginal Effects for the Probability of Employment for Females by Area

\begin{tabular}{|c|c|c|c|c|c|c|c|c|}
\hline & \multicolumn{4}{|c|}{ Provides less than 20 hours of Care } & \multicolumn{4}{|c|}{ Provides at least 20 hours of care } \\
\hline & LESE & ROE & swV & ROW & LESE & ROE & SWV & ROW \\
\hline Aged 20-24 & $-0.095^{\star \star \star}$ & $-0.073^{\star \star \star}$ & $-0.106^{\star \star \star}$ & $-0.068^{* \star \star}$ & $-0.216^{\star \star \star}$ & $-0.108^{\star \star \star}$ & -0.180 & 0.026 \\
\hline Aged 25-29 & $-0.100^{\star \star \star}$ & $-0.063^{\star \star \star}$ & $-0.061^{\star *}$ & $-0.051^{\star \star \star}$ & $-0.226^{\star \star \star}$ & $-0.135^{\star \star \star}$ & $-0.214^{*}$ & -0.009 \\
\hline Aged 30-39 & $-0.098^{\star \star \star}$ & $-0.024^{\star \star \star}$ & 0.014 & -0.009 & $-0.187^{\star \star \star}$ & -0.034 & -0.181 & 0.113 \\
\hline Aged $40-49$ & $-0.027^{\star \star \star}$ & $0.028^{\star * \star}$ & $0.074^{\star \star \star}$ & $0.026^{*}$ & $-0.102^{* \star}$ & 0.009 & -0.036 & 0.153 \\
\hline Aged 50-59 & $-0.186^{\star \star \star}$ & $-0.148^{\star \star \star}$ & $-0.127^{\star \star \star}$ & $-0.155^{\star \star \star}$ & $-0.231^{\star \star \star}$ & $-0.107^{\star \star \star}$ & $-0.265^{*}$ & 0.030 \\
\hline Level 1 qualifications & $0.114^{\star \star \star}$ & $0.114^{\star \star \star}$ & $0.159^{\star \star \star}$ & $0.128^{\star \star \star}$ & $0.158^{\star \star \star}$ & $0.112^{\star \star \star}$ & 0.078 & $0.114^{\star \star \star}$ \\
\hline Level 2 qualifications & $0.145^{\star \star \star}$ & $0.160^{\star \star \star}$ & $0.224^{\star \star \star}$ & $0.175^{* \star \star}$ & $0.201^{\star \star \star}$ & $0.183^{\star \star \star}$ & $0.215^{\star \star \star}$ & $0.173^{\star \star \star}$ \\
\hline Level 3 qualifications & $0.150^{\star \star \star}$ & $0.182^{\star \star \star}$ & $0.260^{\star \star \star}$ & $0.197^{\star \star \star}$ & $0.199^{\star \star \star}$ & $0.252^{\star \star \star}$ & $0.185^{\star}$ & $0.233^{\star \star \star}$ \\
\hline Level $4 / 5$ qualifications & $0.184^{\star \star \star}$ & $0.190^{\star * \star}$ & $0.257^{\star \star \star}$ & $0.201^{\star \star \star}$ & $0.258^{\star \star \star}$ & $0.263^{\star \star \star}$ & $0.175^{\star *}$ & $0.239^{\star \star \star}$ \\
\hline Other qualifications & $0.094^{\star \star \star}$ & $0.097^{\star \star \star}$ & $0.128^{\star \star \star}$ & $0.094^{\star \star \star}$ & $0.170^{\star \star \star}$ & $0.127^{\star \star \star}$ & 0.035 & $0.146^{\star \star \star}$ \\
\hline Mixed & $-0.081^{\star \star \star}$ & $-0.072^{\star \star \star}$ & . & -0.014 & 0.032 & -0.003 & _ & 0.128 \\
\hline Asian & $-0.128^{\star \star \star}$ & $-0.251^{\star \star \star}$ & - & $-0.324^{\star \star \star}$ & $-0.089^{\star \star \star}$ & $-0.182^{\star \star \star}$ & - & $-0.293^{\star \star \star}$ \\
\hline Black & $-0.037^{\star \star \star}$ & -0.005 & - & $-0.142^{*}$ & $0.087^{\star \star \star}$ & 0.059 & - & 0.183 \\
\hline Chinese \& Other & $-0.123^{\star \star \star}$ & $-0.145^{\star \star \star}$ & - & $-0.167^{\star \star \star}$ & -0.053 & -0.095 & - & -0.118 \\
\hline Married & $-0.055^{\star \star \star}$ & $-0.020^{\star \star \star}$ & 0.017 & -0.012 & $-0.047^{\star \star \star}$ & $-0.024^{\star \star \star}$ & -0.007 & 0.015 \\
\hline Dependent children & $-0.170^{\star \star \star}$ & $-0.134^{\star \star \star}$ & $-0.113^{\star \star \star}$ & $-0.131^{\star \star \star}$ & $-0.138^{\star \star \star}$ & $-0.080^{\star \star \star}$ & $-0.127^{\star \star \star}$ & -0.038 \\
\hline Fairly good health & $-0.069^{\star \star \star}$ & $-0.095^{\star \star \star}$ & $-0.206^{\star \star \star}$ & $-0.136^{\star \star \star}$ & $-0.091^{\star \star \star}$ & $-0.102^{\star \star \star}$ & $-0.112^{\star \star \star}$ & $-0.153^{\star \star \star}$ \\
\hline Not good health & $-0.395^{\star \star \star}$ & $-0.461^{\star \star \star}$ & $-0.579^{\star \star \star}$ & $-0.515^{\star \star \star}$ & $-0.266^{\star \star \star}$ & $-0.282^{\star \star \star}$ & $-0.313^{\star \star \star}$ & $-0.341^{\star \star \star}$ \\
\hline Owns house & $0.156^{\star \star \star}$ & $0.212^{* \star \star}$ & $0.277^{\star \star \star}$ & $0.200^{\star * \star}$ & $0.221^{\star \star \star}$ & $0.227^{\star \star \star}$ & $0.308^{\star \star \star}$ & $0.247^{\star \star \star}$ \\
\hline $5+$ in household & $-0.042^{\star \star \star}$ & $-0.061^{\star \star \star}$ & $-0.106^{\star \star \star}$ & $-0.033^{\star \star \star}$ & $-0.044^{\star \star \star}$ & $-0.071^{\star \star \star}$ & -0.054 & $-0.108^{\star \star \star}$ \\
\hline Pseudo R-squared & 0.142 & 0.184 & 0.263 & 0.192 & 0.124 & 0.130 & 0.196 & 0.154 \\
\hline Number of observations & 282088 & 372662 & 9591 & 26937 & 10522 & 19452 & 815 & 1813 \\
\hline
\end{tabular}

Notes: Default categories are lives in SWV, aged 16-19, no qualifications, white, unmarried, no dependent children, general health is good, does not own house and lives in a household with less than 5 people. Marginal effects have been calculated at sample means. ${ }^{*} p<0.1 ;{ }^{* *} p<0.05 ;{ }^{* * *} p<0.01$ (two-tailed tests). Ethnic controls excluded from models estimated for the SWV due to small number of ethnic minority individuals in this area. 
Table 8: Marginal Effects for the Probability of Part-Time Employment for Females by Area

\begin{tabular}{|c|c|c|c|c|c|c|c|c|}
\hline & \multicolumn{4}{|c|}{ Provides less than 20 hours of Care } & \multicolumn{4}{|c|}{ Provides at least 20 hours of care } \\
\hline & LESE & ROE & SWV & ROW & LESE & ROE & SWV & ROW \\
\hline Aged 20-24 & $-0.153^{\star \star \star}$ & $-0.136^{\star \star \star}$ & $-0.107^{\star \star \star}$ & $-0.116^{\star \star \star}$ & 0.046 & 0.002 & 0.232 & $0.292^{*}$ \\
\hline Aged 25-29 & $-0.200^{\star \star \star}$ & $-0.186^{\star \star \star}$ & $-0.135^{\star \star \star}$ & $-0.201^{\star \star \star}$ & 0.006 & -0.067 & 0.184 & 0.236 \\
\hline Aged 30-39 & $-0.153^{* \star *}$ & $-0.135^{\star \star \star}$ & $-0.118^{\star \star \star}$ & $-0.150^{\star \star \star}$ & -0.021 & -0.072 & 0.139 & 0.257 \\
\hline Aged $40-49$ & $-0.148^{* \star *}$ & $-0.142^{\star \star \star}$ & $-0.170^{\star \star \star}$ & $-0.150^{* \star *}$ & -0.087 & $-0.092^{*}$ & -0.048 & 0.242 \\
\hline Aged 50-59 & $-0.017^{\star \star \star}$ & $0.020^{\star \star \star}$ & -0.018 & -0.019 & 0.006 & 0.000 & 0.072 & 0.263 \\
\hline Level 1 qualifications & $-0.070^{\star \star \star}$ & $-0.076^{\star \star \star}$ & $-0.122^{\star \star \star}$ & $-0.055^{\star \star \star}$ & $-0.042^{*}$ & $-0.076^{\star \star \star}$ & $-0.196^{\star *}$ & $-0.146^{\star \star}$ \\
\hline Level 2 qualifications & $-0.097^{\star \star *}$ & $-0.114^{\star \star \star}$ & $-0.152^{* \star \star}$ & $-0.086^{\star \star \star}$ & $-0.068^{\star \star \star}$ & $-0.111^{* \star \star}$ & $-0.182^{* *}$ & $-0.211^{\star \star \star}$ \\
\hline Level 3 qualifications & $-0.109^{\star \star \star}$ & $-0.129^{\star \star \star}$ & $-0.203^{\star \star \star}$ & $-0.089^{\star \star \star}$ & $-0.109^{\star \star \star}$ & $-0.237^{\star \star \star}$ & $-0.258^{\star *}$ & $-0.201^{\star *}$ \\
\hline Level $4 / 5$ qualifications & $-0.192^{\star \star \star}$ & $-0.225^{\star \star \star}$ & $-0.281^{* \star *}$ & $-0.221^{\star \star \star}$ & $-0.097^{\star \star \star}$ & $-0.233^{* \star \star}$ & $-0.448^{\star \star \star}$ & $-0.274^{* \star \star}$ \\
\hline Other qualifications & $-0.064^{\star \star \star}$ & $-0.063^{\star \star \star}$ & -0.050 & $-0.089^{\star \star \star}$ & -0.038 & $-0.128^{\star \star \star}$ & $-0.190^{\star}$ & -0.111 \\
\hline Mixed & $-0.033^{* \star *}$ & -0.003 & - & 0.050 & $-0.173^{\star \star \star}$ & -0.011 & - & $0.339^{* *}$ \\
\hline Asian & $-0.089^{\star \star \star}$ & $-0.107^{\star \star \star}$ & - & -0.080 & $-0.144^{\star \star *}$ & $-0.154^{\star \star \star}$ & - & -0.079 \\
\hline Black & $-0.089^{\star \star \star}$ & $-0.074^{\star \star \star}$ & - & 0.022 & $-0.143^{\star \star \star}$ & $-0.135^{*}$ & - & -0225 \\
\hline Chinese \& Other & $-0.074^{\star \star \star}$ & $-0.074^{\star \star \star}$ & - & -0.024 & $-0.245^{\star \star \star}$ & -0.161 & - & -0.225 \\
\hline Married & $0.157^{\star \star \star}$ & $0.138^{\star \star \star}$ & $0.101^{* *}$ & $0.106^{\star \star \star}$ & $0.158^{\star \star \star}$ & $0.120^{\star \star \star}$ & $0 . \overline{14} 6^{*}$ & 0.064 \\
\hline Dependent children & $0.316^{\star \star \star}$ & $0.311^{\star \star \star}$ & $0.276^{\star \star \star}$ & $0.271^{\star \star \star}$ & $0.244^{\star \star \star}$ & $0.242^{\star \star \star}$ & $0.238^{\star \star \star}$ & $0.234^{\star \star \star}$ \\
\hline Fairly good health & $0.021^{\star \star \star}$ & $0.021^{\star \star \star}$ & 0.004 & $0.018^{*}$ & 0.013 & 0.010 & 0.009 & $0.098^{\star *}$ \\
\hline Not good health & $0.043^{\star \star \star}$ & $0.043^{\star \star \star}$ & 0.036 & 0.025 & 0.015 & 0.014 & -0.134 & 0.002 \\
\hline Owns house & $-0.028^{\star \star \star}$ & $-0.078^{\star \star \star}$ & $-0.117^{\star \star \star}$ & $-0.080^{* \star *}$ & -0.013 & -0.012 & -0.125 & -0.019 \\
\hline $5+$ in household & $0.046^{\star \star \star}$ & $0.046^{\star \star \star}$ & $0.056^{\star \star}$ & $0.059^{\star \star \star}$ & 0.030 & -0.004 & 0.039 & 0.003 \\
\hline Pseudo R-squared & 0.148 & 0.118 & 0.107 & 0.096 & 0.075 & 0.066 & 0.127 & 0.071 \\
\hline Number of observations & 206607 & 269034 & 6034 & 18960 & 4537 & 8144 & 299 & 771 \\
\hline
\end{tabular}

Notes: Default categories are lives in SWV, aged 16-19, no qualifications, white, unmarried, no dependent children, general health is good, does not own house and lives in a household with less than 5 people. Marginal effects have been calculated at sample means. $p^{*}<0.1 ;{ }^{* *} p<0.05 ;{ }^{* * *} p<0.01$ (two-tailed tests). Ethnic controls excluded from models estimated for the SWV due to small number of ethnic minority individuals in this area, whilst the Black and Chinese \& Other categories have been combined for females in the ROW providing at least 20 hours of care per week. 
Table A1: Demographic Statistics for the Top and Bottom 20 English and Welsh UAs/LAs Ranked by the Percentage Providing Care in Each Authority

\begin{tabular}{|c|c|c|c|c|c|c|}
\hline LA/UA & Region & Area & $\begin{array}{l}\text { Population } \\
\text { aged 16-74 }\end{array}$ & $\begin{array}{c}\% \\
\text { Inactive }\end{array}$ & $\begin{array}{l}\text { \% Perm. } \\
\text { Sick }\end{array}$ & $\begin{array}{c}\% \text { providing } \\
\text { care }\end{array}$ \\
\hline Neath Port Talbot & Wales & SWV & 96,217 & 43.78 & 13.58 & 18.20 \\
\hline Merthyr Tydfil & Wales & SWV & 39,794 & 45.66 & 15.93 & 16.61 \\
\hline Torfaen & Wales & SWV & 64,526 & 39.19 & 10.22 & 16.56 \\
\hline North East Derbyshire & East Midlands & ROE & 71,084 & 33.99 & 6.26 & 16.53 \\
\hline Blaenau Gwent & Wales & SWV & 49,487 & 44.28 & 13.78 & 16.49 \\
\hline Bolsover & East Midlands & ROE & 51,744 & 38.91 & 9.60 & 16.37 \\
\hline Carmarthenshire & Wales & ROW & 122,865 & 41.40 & 11.07 & 16.34 \\
\hline Rhondda, Cynon, Taff & Wales & SWV & 165,815 & 42.79 & 12.96 & 16.33 \\
\hline Swansea & Wales & ROW & 161,419 & 41.40 & 9.82 & 16.32 \\
\hline Bridgend & Wales & SWV & 92,421 & 39.05 & 10.73 & 16.29 \\
\hline Caerphilly & Wales & SWV & 121,184 & 40.60 & 12.11 & 16.08 \\
\hline Rotherham & Yorks \& Humbs & ROE & 178,324 & 36.02 & 7.88 & 15.99 \\
\hline St. Helens & North West & ROE & 128,206 & 38.49 & 10.09 & 15.76 \\
\hline Chesterfield & East Midlands & ROE & 71,299 & 35.00 & 7.51 & 15.75 \\
\hline Wirral & North West & ROE & 221,027 & 38.23 & 8.72 & 15.66 \\
\hline Barrow-in-Furness & North West & ROE & 51,217 & 39.17 & 10.81 & 15.64 \\
\hline Barnsley & Yorks \& Humbs & ROE & 157,563 & 39.49 & 10.43 & 15.61 \\
\hline Pembrokeshire & Wales & ROW & 80,760 & 40.25 & 8.20 & 15.42 \\
\hline Mansfield & East Midlands & ROE & 70,508 & 37.74 & 8.65 & 15.42 \\
\hline Portsmouth & South East & LESE & 135,623 & 32.19 & 4.63 & 10.24 \\
\hline Forest Heath & East & LESE & 39,966 & 26.84 & 3.01 & 10.13 \\
\hline Lewisham & London & LESE & 183,123 & 31.08 & 4.83 & 10.01 \\
\hline Merton & London & LESE & 139,461 & 28.32 & 3.13 & 9.99 \\
\hline Rushmoor & South East & LESE & 66,531 & 22.79 & 2.82 & 9.95 \\
\hline Oxford & South East & LESE & 103,946 & 39.14 & 2.98 & 9.88 \\
\hline Bracknell Forest & South East & LESE & 79,769 & 22.58 & 2.59 & 9.80 \\
\hline Hackney & London & LESE & 146,859 & 38.19 & 7.04 & 9.80 \\
\hline City of London & London & LESE & 6,050 & 25.17 & 2.96 & 9.60 \\
\hline Camden & London & LESE & 155,163 & 35.18 & 5.77 & 9.59 \\
\hline Islington & London & LESE & 135,662 & 34.69 & 6.91 & 9.58 \\
\hline Reading & South East & LESE & 106,959 & 28.24 & 3.02 & 9.57 \\
\hline Southwark & London & LESE & 183,492 & 34.14 & 5.31 & 9.57 \\
\hline Isles of Scilly & South West & ROE & 1,589 & 19.07 & 1.20 & 9.42 \\
\hline Haringey & London & LESE & 162,705 & 34.53 & 5.24 & 9.16 \\
\hline Lambeth & London & LESE & 203,973 & 29.06 & 4.58 & 8.49 \\
\hline Kensington \& Chelsea & London & LESE & 124,870 & 34.37 & 4.04 & 8.45 \\
\hline $\begin{array}{l}\text { Hammersmith \& } \\
\text { Fulham }\end{array}$ & London & LESE & 129,804 & 30.57 & 4.73 & 8.33 \\
\hline Westminster & London & LESE & 146,477 & 34.01 & 4.71 & 8.14 \\
\hline Wandsworth & London & LESE & 204,651 & 26.69 & 3.69 & 7.82 \\
\hline
\end{tabular}


Table A2: Grouped Weekly Hours of Work (in percentages) by Grouped Weekly Hours of Care

\begin{tabular}{|c|c|c|c|c|c|c|c|c|}
\hline \multirow{3}{*}{$\begin{array}{l}\text { Work } \\
\text { hours }\end{array}$} & \multicolumn{8}{|c|}{ Males } \\
\hline & \multicolumn{4}{|c|}{ LESE (Care hours) } & \multicolumn{4}{|c|}{ ROE (Care hours) } \\
\hline & 0 & $1-19$ & $20-49$ & $50+$ & 0 & $1-19$ & $20-49$ & $50+$ \\
\hline $1-15$ & 3.3 & 3.5 & 3.9 & 3.5 & 3.1 & 3.0 & 3.4 & 3.1 \\
\hline $16-29$ & 5.5 & 7.2 & 7.2 & 7.3 & 5.8 & 6.9 & 7.8 & 8.4 \\
\hline $30-37$ & 13.5 & 14.3 & 14.5 & 14.0 & 15.8 & 16.5 & 16.7 & 17.2 \\
\hline $38-48$ & 51.8 & 48.6 & 52.1 & 47.8 & 52.4 & 49.6 & 50.5 & 48.7 \\
\hline $49+$ & 25.9 & 26.4 & 22.4 & 27.3 & 23.0 & 24.1 & 21.6 & 22.3 \\
\hline \multirow{2}{*}{$\begin{array}{l}\text { Work } \\
\text { hours }\end{array}$} & \multicolumn{4}{|c|}{ svW (Care hours) } & \multicolumn{4}{|c|}{ ROW (Care hours) } \\
\hline & 0 & $1-19$ & $20-49$ & $50+$ & 0 & $1-19$ & $20-49$ & $50+$ \\
\hline $1-15$ & 2.7 & 2.1 & 3.4 & 0.8 & 3.4 & 3.0 & 3.3 & 3.2 \\
\hline $16-29$ & 4.4 & 4.4 & 4.2 & 7.3 & 6.3 & 7.1 & 7.0 & 7.7 \\
\hline $30-37$ & 17.3 & 19.8 & 17.0 & 21.1 & 15.4 & 15.4 & 13.7 & 10.9 \\
\hline $38-48$ & 57.9 & 54.9 & 61.9 & 46.3 & 51.5 & 48.4 & 52.8 & 50.6 \\
\hline \multirow[t]{2}{*}{$49+$} & 17.8 & 18.9 & 13.6 & 24.4 & 23.3 & 26.0 & 23.3 & 27.6 \\
\hline & \multicolumn{8}{|c|}{ Females } \\
\hline \multirow{2}{*}{$\begin{array}{l}\text { Work } \\
\text { hours }\end{array}$} & \multicolumn{4}{|c|}{ LESE (Care hours) } & \multicolumn{4}{|c|}{ ROE (Care hours) } \\
\hline & 0 & $1-19$ & $20-49$ & $50+$ & 0 & $1-19$ & $20-49$ & $50+$ \\
\hline $1-15$ & 12.6 & 14.8 & 17.4 & 23.9 & 13.3 & 13.8 & 19.6 & 25.0 \\
\hline $16-29$ & 24.0 & 30.6 & 29.2 & 33.1 & 29.8 & 34.0 & 33.7 & 34.9 \\
\hline $30-37$ & 22.1 & 20.9 & 22.1 & 16.3 & 23.2 & 22.6 & 20.9 & 17.3 \\
\hline $38-48$ & 33.1 & 26.0 & 25.0 & 19.3 & 27.8 & 23.4 & 20.4 & 15.9 \\
\hline $49+$ & 8.3 & 7.7 & 6.3 & 7.4 & 6.0 & 6.3 & 5.3 & 7.0 \\
\hline \multirow{2}{*}{$\begin{array}{l}\text { Work } \\
\text { hours }\end{array}$} & \multicolumn{4}{|c|}{ SVW (Care hours) } & \multicolumn{4}{|c|}{ ROW (Care hours) } \\
\hline & 0 & $1-19$ & $20-49$ & $50+$ & 0 & $1-19$ & $20-49$ & $50+$ \\
\hline $1-15$ & 12.1 & 12.1 & 14.9 & 21.5 & 12.4 & 13.9 & 16.2 & 21.1 \\
\hline $16-29$ & 28.7 & 32.1 & 34.0 & 33.5 & 30.6 & 32.9 & 35.4 & 30.2 \\
\hline $30-37$ & 26.1 & 26.3 & 22.7 & 23.4 & 23.1 & 23.4 & 18.1 & 19.4 \\
\hline $38-48$ & 29.0 & 24.8 & 24.8 & 16.5 & 27.3 & 22.0 & 22.0 & 17.2 \\
\hline $49+$ & 4.4 & 4.7 & 3.6 & 5.1 & 6.6 & 7.7 & 8.2 & 12.3 \\
\hline
\end{tabular}


Table A3: Means of Explanatory Variables in Employment Equations by Area

\begin{tabular}{|c|c|c|c|c|c|c|c|c|}
\hline & \multicolumn{4}{|c|}{ Males } & \multicolumn{4}{|c|}{ Females } \\
\hline & LESE & ROE & swV & ROW & LESE & ROE & swV & ROW \\
\hline $20+$ hours of care & 0.022 & 0.031 & 0.052 & 0.038 & 0.036 & 0.050 & 0.078 & 0.063 \\
\hline Aged 16-19 & 0.045 & 0.052 & 0.050 & 0.049 & 0.046 & 0.055 & 0.052 & 0.051 \\
\hline Aged 20-24 & 0.084 & 0.080 & 0.085 & 0.084 & 0.093 & 0.088 & 0.091 & 0.087 \\
\hline Aged 25-29 & 0.115 & 0.097 & 0.099 & 0.095 & 0.127 & 0.109 & 0.103 & 0.104 \\
\hline Aged 30-39 & 0.265 & 0.246 & 0.240 & 0.230 & 0.287 & 0.272 & 0.269 & 0.263 \\
\hline Aged 40-49 & 0.219 & 0.223 & 0.213 & 0.227 & 0.234 & 0.243 & 0.243 & 0.246 \\
\hline Aged 50-59 & 0.199 & 0.217 & 0.225 & 0.225 & 0.214 & 0.234 & 0.242 & 0.249 \\
\hline Aged 60-64 & 0.074 & 0.085 & 0.088 & 0.090 & - & _- & _- & - \\
\hline No qualifications & 0.199 & 0.258 & 0.353 & 0.256 & 0.192 & 0.255 & 0.340 & 0.246 \\
\hline Level 1 qualifications & 0.180 & 0.198 & 0.181 & 0.178 & 0.186 & 0.204 & 0.196 & 0.185 \\
\hline Level 2 qualifications & 0.186 & 0.191 & 0.180 & 0.199 & 0.224 & 0.228 & 0.222 & 0.240 \\
\hline Level 3 qualifications & 0.087 & 0.073 & 0.050 & 0.070 & 0.094 & 0.080 & 0.058 & 0.074 \\
\hline Level 4/5 qualifications & 0.267 & 0.182 & 0.128 & 0.197 & 0.261 & 0.185 & 0.141 & 0.212 \\
\hline Other qualifications & 0.082 & 0.098 & 0.108 & 0.100 & 0.043 & 0.048 & 0.044 & 0.043 \\
\hline White & 0.883 & 0.947 & 0.990 & 0.978 & 0.866 & 0.943 & 0.990 & 0.978 \\
\hline Mixed & 0.014 & 0.006 & 0.003 & 0.005 & 0.017 & 0.007 & 0.004 & 0.006 \\
\hline Asian & 0.057 & 0.035 & 0.004 & 0.010 & 0.057 & 0.037 & 0.004 & 0.009 \\
\hline Black & 0.034 & 0.008 & 0.001 & 0.003 & 0.044 & 0.008 & 0.000 & 0.002 \\
\hline Chinese \& Other & 0.012 & 0.004 & 0.002 & 0.004 & 0.017 & 0.005 & 0.002 & 0.005 \\
\hline Married & 0.511 & 0.539 & 0.549 & 0.542 & 0.511 & 0.541 & 0.545 & 0.545 \\
\hline Dependent children & 0.373 & 0.391 & 0.398 & 0.391 & 0.461 & 0.494 & 0.530 & 0.496 \\
\hline Good health & 0.743 & 0.697 & 0.626 & 0.694 & 0.710 & 0.674 & 0.586 & 0.668 \\
\hline Fairly good health & 0.193 & 0.211 & 0.218 & 0.202 & 0.224 & 0.240 & 0.269 & 0.233 \\
\hline Not good health & 0.065 & 0.092 & 0.156 & 0.104 & 0.067 & 0.086 & 0.146 & 0.099 \\
\hline Owns house & 0.720 & 0.765 & 0.793 & 0.774 & 0.697 & 0.738 & 0.742 & 0.736 \\
\hline $5+$ in household & 0.135 & 0.121 & 0.114 & 0.123 & 0.139 & 0.127 & 0.119 & 0.133 \\
\hline Number of observations & 306788 & 419753 & 11043 & 30541 & 292610 & 392114 & 10406 & 28750 \\
\hline
\end{tabular}

